\title{
SELF DISCLOSURE DALAM MEMBENTUK LEVEL HUBUNGAN INTERPERSONAL PERSPEKTIF GENDER DI ASRAMA PUTRA DAN PUTRI STAIN PAREPARE
}

\author{
Hasniar, Muhammad Qadaruddin, Nurhakki \\ Institut Agama Islam Negeri (IAIN) Parepare \\ Email: ratualimah@gmail.com
}

\begin{abstract}
Self-disclosure or "self disclosure" can be interpreted as giving information about yourself to others. The information provided can include various things such as life experiences, feelings, emotions, opinions, ideals, etc. Self-disclosure needs to be done by the dormitory because it is one way to adapt to the new environment. Self-disclosure, among others, is influenced by gender differences. Self-disclosure is closely related to effective interpersonal communication.

The type of research conducted by the researcher is descriptive qualitative research using interviews, observation and documentation to find the data to be analyzed using triangulation techniques. The results of this study indicate that STAIN Parepare male dormitory and female dormitory students are able to build interpersonal relationships by means of self-disclosure and are able to provide an overview of the existence of gender differences in terms of the process of building interpersonal relationships. The relationship stage that can be formed through the sixth stage of the process becomes a reference for discussion to develop interpersonal relationships. Interpersonal relationships that occur in the STAIN Parepare male and female dormitories are in the management of psychological data levels to be able to do self disclosure. son or being in the category area area, the purpose of open area is where the residents of STAIN Parepare dormitories are more at an open level in order to be able to build good relationships. Self disclosure is a good system that is also applied by residents of the Parepare STAIN dormitory to form interpersonal relationships.
\end{abstract}

Keywords: Self Disclosure, Hubungan Interpersonal

\section{PENDAHULUAN}

Pada umumnya mahasiswa yang berada di asrama notabenenya berasal dari masing-masing daerah yang berbeda, sehingga mereka memiliki simbol tersendiri, serta karakter, watak, ciri khas masing-masing. Disanalah mereka mulai beradaptasi dengan teman-teman dan lingkungan yang tergolong baru bagi mereka, sehingga mahasiswa yang berada pada asrama tersebut di petak-petakkan 
di masing-masing ruangan dan dituntut untuk saling berinteraksi sesama penghuni asrama yang lainnya. Pada dasarnya untuk beradaptasi di lingkungan yang tergolong baru butuh kemampuan dan kesediaan diri untuk melebur dan menyatu dengan yang lain agar bisa mencapai suatu hubungan yang harmonis. Hal tersebut tidaklah jauh berbeda dengan yang terjadi di ruanglingkup asrama STAIN Parepare.

Berdasarkan hasil survei lapangan jumlah penghuni Asrama Putri pada tahun 2015 yaitu 176 orang dan jumlah penghuni yang keluar sebelum waktu yang di tentukan yaitu 31 orang. Pada tahun 2016 jumlah penghuni asrama putri yaitu 137 orang dan penghuni yang keluar sekitar 3 orang. Jumlah penghuni Asrama putra pada tahun 2014 yaitu 50 orang dan jumlah penghuni yang keluar yaitu 7 orang. Pada tahun 2015 jumlah penghuni asrama putra yaitu 40 orang dan sampai sekarang belum ada yang keluar. Realitas yang terjadi bahwa dari tahun 2014 dan 2015 penghuni asrama putri yang keluar semakin menurun begitu pun sebaliknya penghuni asrama putrakeluar sebelum waktu yang ditentukan.

Jumlah penghuni dari masing-masing kamar dihuni oleh 4 mahasiswa, namun terkadang calon penghuni asrama maupun sudah menjadi penghuni asrama memilih-milih kamar yang sesuai dengan keinginannya. Realitas yang terjadi teman sekamar langsung ditentukan oleh pembina asrama, dan diberikan langsung kepada pihak yang berwewenang. Setiap penghuni asrama selalu merasa terbebani dengan aturan-aturan yang sifatnya membatasi seperti halnya dalam ketetapan waktu pulang sebelum jam 10. Inilah yang membuat penghuni asrama terkadang merasa dibatasi karena sebagian besar penghuni asrama mengikuti kegiatan internal kampus yang disebut orgarnisasi.

Hal ini menyebabkan diantara mereka mengalami kesulitan ketika berinteraksi dengan orang-orang dan lingkungan baru. Hal ini bisa disebabkan oleh faktor personal dan situasional. Faktor personal seperti kepribadian orang tersebut, apakah mereka tipe orang yang terbuka atau tertutup. Bagi mereka yang tertutup akan cenderung sulit untuk menyesuaikan diri, sehingga mereka tidak 
akan mempunyai banyak teman. Faktor situasional misalnya, kendala tersebut terkadang dalam penyesuaian budaya, diantaranya adalah masalah bahasa.

Persoalan budaya akan menjadi masalah ketika dua atau beberapa orang melakukan komunikasi tetapi antara si komunikator dan komunikan memiliki makna yang berbeda terhadap suatu pesan yang disampaikan. Kendala ini akan berpengaruh dalam penyesuaian diri yang dilakukan seorang. Apalagi bila dikaitkan dengan faktor personalnya sendiri.

Apabila mereka dapat mengatasi kendala tersebut, baik itu faktor personal maupun faktor situasionalnya, maka biasanya mereka akan mudah dalam melakukan dan melanjutkan interaksi diantara mereka. Bila pada awalnya masih terkesan kaku dan canggung maka lama kelamaan semua akan berjalan normal. Kendala tersebut bisa diatasi dengan membina hubungan yang baik antara mereka. Hubungan itu barulah akan tercipta melalui komunikasi yang baik.

Sebagaimana perintah Allah SWT dalam surat An Nisa ayat 8 tentang cara penyampaian yang lemah-lembut (qaulan ma'rufa) perkataan yang baik, yang berbunyi:

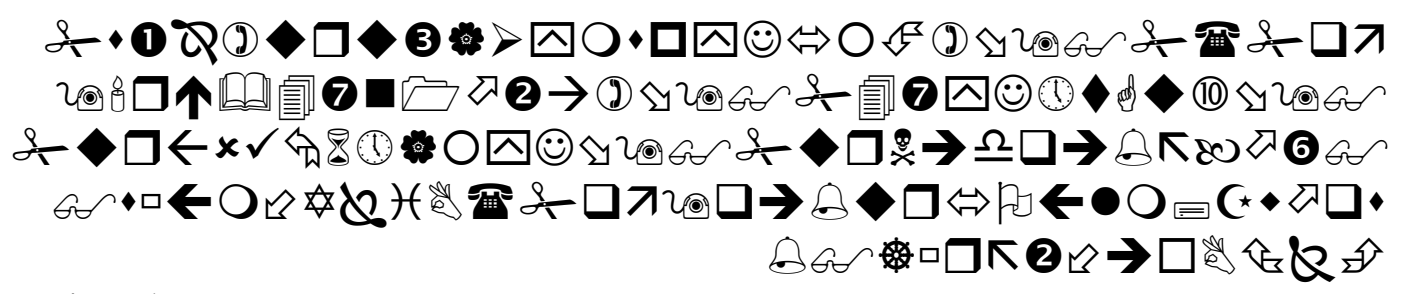

Terjemahannya:

Dan apabila sewaktu pembagian itu hadir kerabat, anak yatim dan orang miskin, Maka berilah mereka dari harta itu (sekedarnya) dan ucapkanlah kepada mereka Perkataan yang baik. ${ }^{1}$

Sangatlah sulit untuk membangun suatu hubungan tanpa adanya komunikasi yang mendasarinya. Komunikasi yang paling efektif bagi mereka yang tinggal bersama di sebuah asrama tentu saja, Ketika komunikasi interpersonal yang terjadi telah berlangsung efektif maka akan terbuka kemungkinan adanya pengungkapan diri. Kesediaan untuk membuka diri (selfdisclosure) setidaknya akan meringankan ketegangan-keteganganya yang

Departemen Agama RI, Alquran dan Terjemahannya, (Bandung: Mizan bunaya 
dialami ketika mulai memasuki lingkungan baru. Dimana mereka mulai membuka diri dan berinteraksi dengan orang-orang baru, dalam hal ini teman-teman di asrama dan teman kuliah.

\section{PEMBAHASAN}

Tahap Pengembangan Hubungan Interpersonal di Asrama Putra dan Putri STAIN Parepare dalam Perspektif Gender.

Sebelum mengetahui proses untuk membangun hubungan interpesonal, maka peneliti terlebih dahulu mendeskripsikan tentang level hubungan interpersonal yang telah dijelaskan pada bab 2 dalam penelitian ini yang terbagi menjadi 3 bagian, yaitu level kultural, level sosiologis dan level psikologis. Hal tersebut menjadi ukuran dari peneliti untuk memahami serta menarik benang merah tentang hubungan interpersonal yang terjalin di asrama purta dan putri STAIN Parepare.

Menurut Umar mengatakan bahwa:

Untuk memberikan penilaian kepada seseorang seperti halnya temanteman seasrama atau teman sekamar dalam satu asrama, sering ki' mengambil informasi berdasarkan dari data yang kita dapatkan dari beberapa sumber, baik sumber dari penjelasan orang-orang yang berada di sekitar kita maupun dari apa yang kita ketahui berdasarkan dari penjelasannya teman ta' sendiri. ${ }^{2}$

Data di atas menegaskan bahwa untuk mampu memahami teman-teman yang ada di dalam ruanglingkup asrama maka didapatkan berdasarkan dari uraian atau informasi teman-teman di asrama dan juga berdasarkan dari keterbukaan diri teman yang ingin diketahui. Hal ini sesuai dengan teori yang kemudian membantu penelti dalam menemukan data tersebut, yaitu pada jendela jauhari yang menerangkan tentang keterbukaan diri pada daerah tertutup memiliki sistem penilaian secara spesifik untuk mengambil kesimpulan terkait diri seseorang.

Lebih lanjut Umar menjelaskan bahwa: 
Biasanya kalau kita nilai teman ta' di awal perkenalan biasanya adami ukuran penilaian ta' sama teman sekamar misalnya. Pertamanya kita tau bahwa baek orangnya, ternyata lama-lama kelamaan hal tersebut berubah sampai kita dapatkan lagi pemahaman baru tentang dirinya teman ta bahwa ternyata tidak bagus ple ini orang. Jadi biasanya kalau kita nilai orang dari luar biasanya salahki nilai orang itu. ${ }^{3}$

Penjelasan di atas memberikan pandangan kepada peneliti bahwa dalam pemberian penilaian terhadap suatu sikap atau kebiasaan seseorang, maka diharuskan untuk memiliki data serta pengelolaan data yang memiliki metode yang jelas untuk mampu memahami kepribadian seseorang terkhusus pada self disclosure. Berdasarkan dari hal tersebut, peneliti akan menyimpulkan pada akhir pembahasan setelah peneliti mendeskripsikan proses yang terjadi di asrama purta dan putri STAIN Parepare dalam membangun hubungan interpersonal dengan menggunakan self disclosure.

Proses untuk membentuk hubungan interpersonal antara penghuni asrama putra dan putri di STAIN Parepare itu diawali dengan terjadinya proses interaksi. Sehingga interaksi ini mengharuskan terjadinya sebuah proses kerja sama, terkadang pula menjadi sebuah pertikaian yang dimulai dari ketidak samaan pendapat sampai adanya ketersinggungan satu dengan yang lainnya.

Berdasarkan dari penjelasan di atas Jafar menjelaskan bahwa:

Sulit ki' saling kenal mengenal satu sama lain kalau tidak membiasakan diri ki' berbaur dengan teman-teman ta' yang ada di asrama. Jadi biasanya itu kalau pendiamki palingan yang kita temani itu hanya teman sekamarta ji. ${ }^{4}$

Data di atas menjelaskan bahwa hubungan yang terjadi melalui tahap sisiologis lebih mengarah kepada personal mahasiswa tersebut. Keseharian dan pribadi diri dalam bergaul akan mempengaruhi proses self disclosure seseorang. Penjelasan tersebut dipertegas pula oleh Hasni Kadir mengatakan bahwa:

Kalau menurut saya, memang harus ki' bergaul sama teman-teman ta seasrama karena kalo tidak, maka sedikitji pasti teman ta. Tapi kalau bergaul ki' juga haruski bisa pahami orang karena tidak semua orang

${ }^{3}$ Umar, Penghuni Asrama PutraSTAIN Parepare, Wawancarapada tanggal 20 Januari

${ }^{4}$ Jafar,Penghuni Asrama PutraSTAIN Parepare, Wawancarapada tanggal 30 Januari 2016 
sama. Maksudnya, biasaki' lansung saja tidak nasuka orang biasa juga ada orang yang cepat akrab sama kita, mungkin karena naliat jki sekilas.

Hasil wawancara tersebut peneliti dapat menyimpulkan bahwa interaksi merupakan hal yang sangat mampu mengarahkan sebuah hubungan, baik yang bersifat positif maupun negatif.

Data yang ditemukan peneliti dalam pembahasan hubungan interpersonal Asrama STAIN Parepare belumlah cukup ketika rujukannya hanyalah pembahasan di atas. Sehingga peneliti berusaha untuk menggali dan mencari lebih jauh terkait hubungan interpersonal yang terjadi di Asrama STAIN Parepare.

Ukuran hubungan interpersonal yang tergolong ideal itu mampu tercapai ketika melaksanakan tahapan-tahapan yang tertuang dalam tinjauan teoritis pada penilitan ini. Adapun tahapan-tahapan dalam membangun hubungan interpersonal tersebut yaitu tahap inisiasi, tahap pengembangan, tahap intensifikasi, tahap formalisasi, tahap redefinisi dan tahap deteriorasi.

Tahap pertama yaitutahap inisiasi merupakan dua atau beberapa orang yang saling memerhatikan dan menyesuaikan perilaku satu sama lain untuk mengawali pertemuan. Sering kali pesan-pesan awal yang dipakai seorang individu untuk penyesuaian adalah nonverbal—senyum, pandang sekilat, jabat tangan, gerakan, atau penampilan. Jika hubungan berlanjut akan muncul proses timbal balik secara progresif dengan menunjukkan tindakan, posisi, penampilan, dan gerak tubuh

Dari penjelasan di atas Abd.Rahim menjelaskan bahwa:

Senyuman biasanya seringki' lakukan sama teman-teman ta, baik yang kenal maupun yang tidak kita kenal. Karena biasanya orang kalau tidak di kasi' ekspresi seperti itu atau muka' datar ji dikasikan orang, biasa na cap mki sombong dan lain-lain. ${ }^{6}$ Januari 2016

${ }^{5}$ Hasni Kadir, Penghuni Asrama PutriSTAIN Parepare, Wawancarapada tanggal 18

${ }^{6}$ Abd. Rahim, Penghuni Asrama PutraSTAIN Parepare, Wawancara pada tanggal 3 Februari 2016 
Berdasarkan dari hasil wawancara peneliti kepada Abd. Rahim dapat diketahui bahwa pada proses interaksi di awal dapat dilakukan melalui interaksi nonverbal dalam hal ini kebiasaan senyum yang dilakukan oleh narasumber sehingga mendapatkan proses umpan balik. Lebih lanjut Ramdana menjelaskan bahwa:

Waktu di awal masuk asrama tidak ada satupun teman-teman yang ada di asrama kukenal, tapi karena sering jki baku sapa jadi cepatki akrab sama teman-teman di asrama.

Melihat pembahasan yang ada di atas, maka hubungan yang terbangun di asrama diawali dari proses saling berinteraksi secara penyesuaian nonverbal. Hal tersebut berdasarkan dari penjelasan di atas agar hubungan yang terbangun tidak mengarah kepada hal-hal yang negatif, serta mengarah kepada hubungan dan penilaian yang baik. Hubungan yang terjalin pun diharapkan agar mampu intensif agar mampu meningkatkan hubungan pada tahap inisiasi berjalan sesuai dengan apa yang diharapkan. Seperti yang dikemukakan oleh Rukmana mengatakan:

Bisa ki' akrab dengan teman-teman ta' kalau bagus cara ta' bergaul. Bagus yang kumaksud disini bisa ki' hargai orang. Terus seringki jalin hubungan silaturrahmi sesama kita yang ada di asrama. Biasanya kalo ada mi teman ta yang duduk nongkrong di area asrama, kalau saya biasanya lansung datang bergabung disitu saya awali dengan senyum sama teman-teman dan berjabat tangan. Kalau tidak pernah peki' ketemu sebelumnya jadi yang kulakukan itu berjabat tangan sekaligus sebut nama mka juga. Sering juga karena sudah mka sebut nama, nasebut mi juga namanya itu teman-teman waktu pertamaku di asrama. ${ }^{8}$

Data di atas memnggambarkan bahwa dalam membangun hubungan diharuskan agar adanya proses kesinambungan atau berkelanjutan dari proses awal ke proses selanjutnya. Agar hubungan yang ingin dibangun dapat berjalan sesusai dengan apa yang diharapkan. Terkait pembahasan tersebut, Umar memberikan penjelasan bahwa:

\footnotetext{
${ }^{7}$ Ramdana, Penghuni Asrama PutriSTAIN Parepare, Wawancara pada tanggal 18 Januari 2016

${ }^{8}$ Rukmana, Penghuni Asrama PutriSTAIN Parepare, Wawancara pada tanggal 8 februari 2016
} 
Awalnya toh senyum-senyum jki, terus karena dalam asrama jki semua jadi sering ki ketemu baku liat-liat jadi cepat jki akrab sebenarnya kalo sesama teman-teman di dalam asrama.

Hasil wawancara di atas mampu memberikan penjelasan kepada peneliti bahwa pada tahapan inisiasi tersebut dilaksanakan penghuni asrama, baik putra maupun putri. Sehingga peneliti dapat menyimpulkan bahwa benar adanya hubungan interpersonal terjadi melalui tahap inisiasi atau tahap awal pertemuan antara penghuni asrama STAIN Parepare. Mereka saling menyesuaikan diri dalam mengawali sebuah pertemuan. Baik menggunakan lisan maupun non-lisan atau dengan kata lain, dominan mengawalinya dengan menggunakan pesan awal yaitu nonverbal.

Tahap kedua yakni tahappengembangan atau eksplorasi, dilakukan segera setelah waktu sejak pertemuan awal, karena peserta mulai mengeksplorasi potensi orang lain dan kemungkinan untuk mewujudkan hubungan. Pada tahap ini kita mengumpulkan informasi tentang gaya, motif, minat, dan nilai dari orang lain. Pengetahuan ini berfungsi sebagai dasar untuk menilai manfaat melanjutkan hubungan.

Tahap ini dicirikan oleh pembicaraan kecil-tapi arti penting pembicaraaan ini tidak kecil. Semua hubungan dimulai dengan para peserta mencoba untuk mengetahui informasi tentang satu sama lain. Selain mengamati seperti apa seseorang yang tampak dari luar, kita perlu tahu seperti apa orang itu dari sisi "dalam" agar ada peluang untuk berbicara secara nyaman tentang suatu topik dengan lebih mendalam, dari sekadar topik cuaca atau skor pertandingan sepak bola terakhir. Adakalanya percakapan ini adalah sulit, karena kita benarbenar tidak tahu apa yang orang lain suka untuk dibicarakan. Kadang-kadang percakapan ini diformalkan seperti pemeriksaan dokter yang melibatkan sederet pertanyaan khusus untuk melakukan diagnosa.

Meskipun eksplorasi merupakan pekerjaan sulit, adalah sering menyenangkan untuk mengenal orang lain dan mendengar apa yang ia katakan

\footnotetext{
${ }^{9}$ Umar, Penghuni Asrama PutraSTAIN Parepare, Wawancarapada tanggal 20 Januari 
tentang topik tertentu. Percakapan selanjutnya menjadi lebih mudah karena kita telah belajar lebih banyak tentang orang-orang dan mengenal kesukaan dan ketidaksukaan mereka secara lebih baik.

Berdasarkan penjelasan tersebut Hasnawati menjelaskan bahwa:

Waktu pertama kali tiba di Parepare dan ditempatkan ka' di Asrama STAIN Parepare, saya tidak mengenal teman-teman Asrama. Akan tetapi dalam tahapan menyesuaikan diri, terkadang saya mencoba untuk mengakrabkan diri. Prosesnyapun sangat sederhana menurut saya, hal itu dikarenakan saya cukup mencoba membangun hubungan atau interaksi dengan teman-teman sebanyak mungkin untuk mampu mengakrabkan diri dengan lingkungan sekitar Asrama. Dalam proses tersebut, terkadang mampu ki' memilih yang mana asyik diajakin berkomunikasi atau membangun hubungan, sehingga bisa mki memilih siapa yang akan menjadi sahabat kita.

Hasil wawancara di atas memberikan penjelasan bahwa keakraban dalam hubugan dapat lebih cepat ketika interaksi yang dilakukan itu menyenangkan. Hubungan yang berkelanjutan sampai pada keakraban diharuskan adanya eksplorasi kesenangan dalam berinteraksi satu sama lain. Pada pembahasan tersebut lebih lanjut Hasnawati menjelaskan:

Di awal pertemanan kita dengan teman-teman sesama asrama muncul berbagai macam kisah, cerita dan pengalaman masing-masing. Biasa saya yang jelaskan sama teman-teman tentang kisahku atau asalku darimana dan biasa juga sebaliknya. Dari cerita-cerita itu mi yang kasi' akrab ka' dengan teman-teman di asrama.

Berdasarkan dari penjelasan di atas yang mendeskripsikan tentang adanya interaksi yang lebih mendalam lagi dibandingkan dengan tahapan sebelumnya. Hal ini menegaskan bahwa dalam tahapan hubungan yang dilakukan di asrama STAIN Parepare baik asrama putra ataupun putri terjalin berdasarkan daripada tahap inisiasi dan tahap ekspolrasi. Jamaluddin juga menjelaskan tentang tahapan hubungannya yang dilakukan di asrama putra yang mengatakan bahwa:

\footnotetext{
${ }^{10}$ Hasnawati,Penghuni Asrama PutriSTAIN Parepare, Wawancarapada tanggal 25 Januari 2016

${ }^{11}$ Hasnawati,Penghuni Asrama PutriSTAIN Parepare, Wawancarapada tanggal 25 Januari 
Proses dalam memilih teman itu tergantung yang mana mampu membuat kita senang berada di dekat teman-teman yang berada di Asrama. Seperti halnya kalau misal cerita-cerita meki. Banyak yang dicerita teman-teman yang ada di asrama terkesan harus pki' peka. Maksudnya setiap apa yang dicerita teman ta' alangkah tidak enaknya kalo kita tinggalkan disaat tidak kita suka pembahasannya. Biasanya juga begitu sebaliknya, kalau pembahasan ta tidak nasuka' teman. Jadi kalo itu terjadi pasti yang tidak senang itu pasti lebih memilikh diam, karena saya juga begitu ka'.

Berdasarkan penjelasan dari narasumber di atas menerangkan bahwa interkasi membutuhkan pula kesesuaian pembahasan dan pemahaman, hal ini bertujuan agar hubungan yang diinginkan dapat tercarapai sesuai dengan apa yang diharapkan. Terkait dari penjelasan tersebut, Hasni kadir Memberikan pula penjelasan yang mengatakan:

Saya secara pribadi orangnya pemalu, sehingga waktu di awal-awal ka' di asrma, sulit ka' untuk mengungkapkan diri secara langsung. Tapi, pada prosesku untuk mendapatkan teman yang memang saya sering sama itu tergantung siapa yang datangi ka' dan sopan juga. Nah, kalo begitumi itu orang, sayapun juga memberikan respon yang baik sama teman. Sehingga bisa meki'akrab dan sering meki sama ketimbang teman-teman yang lain. 13

Tahap pengembangan ini cenderung memberikan gambaran bahwa interaksi yang dilakukan seseorang terhadap pengungkapan dirinya terkesan telah mampu memberikan penilaian terhadap seseorang untuk memilih yang akan dijadikannya kawan dekat. Hal tersebut berdasarkan dari penjelasan penghuni asrma STAIN Parepare, baik putra maupun putri telah melaksanakan tahap pengembangan tersebut.

Tahap ketiga tentang intensifikasi, jika hubungan mengalami kemajuan, bergerak ke tahap ketiga, yang oleh Mark Knapp dan Anita Vangelisti diberi nama intensifying stage (tahap intensifikasi). Dalam mencapai tingkat ini, peserta telah tiba pada suatu keputusan — mengatakan atau tidak mengatakanbahwa mereka ingin melanjutkan hubungan. Jika hubungan berlanjut, mereka mesti mendapatkan cukup banyak pengetahuan tentang satu sama lain, dan pada saat yang sama, membuat sejumlah aturan bersama, bahasa bersama, dan

\footnotetext{
${ }^{12}$ Jamaluddin,Penghuni Asrama PutraSTAIN Parepare, Wawancarapada tanggal 10 Februari 2016

${ }^{13}$ Hasni Kadir, Penghuni Asrama PutriSTAIN Parepare, Wawancara pada tanggal 18 Januari 2016
} 
memahami ciri-ciri hubungan ritual. Hubungan dalam tahap ini hubungan bisa gagal, memburuk, atau terus berkembang.

Pada tahap ini orang sering menganggap diri mereka "teman dekat". Orang pada tahap ini lebih cenderung untuk berbagi rahasia lebih dalam (seperti takut gagal, atau masalah penggunaan narkoba di masa lalu), menggunakan istilah atau nama panggilan yang lebih pribadi untuk masing-masing, dan mengembangkan simbol-simbol yang mempunyai makna pribadi. Misalnya, barang-barang yang dibeli bersama (seperti lampu favorit atau kursi) atau peristiwa yang dialami bersama (seperti basah kuyup dalam hujan badai sambil menunggu taksi) digunakan sebagai dasar untuk percakapan. Kita juga mengintensifikan hubungan kita secara nonverbal dengan menyentuh satu sama lain lebih sering dan dalam cara yang lebih intim. Terkait dari penjelasan tersebut, Hasnawati menjelaskan bahwa:

Saya pernah lalui hal yang dibahas di atas, ada beberapa teman yang memang dalam keseharian itu kami sering sama. Jadi keakraban sama yang lebih sering ketimbang teman-teman yang lain. Hal ini tentunya bisa buat ki' sudah saling mengenal identitas secara mendalam.Baik perkenalannya pada ruanglingkup keluarga masing-masing ataupun profil yang lain termasuk dari mana asal sekolahnya anak keberapa dan berapa bersaudara bahkan biasanya, dikarenakan terlalu saling mengetahui ki itu sampe-sampe nama dari keseluruhan keluarganya di tau'mi juga.Jadi biasa ada nama panggilan rumahnya teman ta di rumahnya, sehingga dipanggil begitumi juga kita. ${ }^{14}$

Penjelasan di atas memberikan pemahaman kepada peneliti bahwa hubungan yang kemudian berkelanjutan pada tahap ini lebih menekankan pada kesesuaian secara dalam lagi dari tahapan-tahapan sebelumnya, adanya panggilan batin dikarenakan adanya kesamaan proses keinginan sehingga dapat mencapai tahap hubungan ini.

Tahapan intensifikasi lebih mengutamakan pengungkapan diri seseorang terhadap suatu hubungan yang lebih mengenal kepribadian secara pergaulan, sehingga terkesan akan memiliki respon yang saling memahami satu sama lain. Berdasarkan deskripsi hasil penelitian di atas, peneliti dapat menyimpulkan bahwa

\footnotetext{
${ }^{14}$ Hasnawati,Penghuni Asrama PutriSTAIN Parepare, Wawancarapada tanggal 25 Januri 
dalam pembahasan pada tahapan intensifikasi tersebut menggambarkan bahwa penghuni Asrama STAIN Parepare menerapkan proses intentensifikasi dalam interaksi interpersonal pada ruanglingkup Asrama STAIN Parepare.

Tahap keempat yaitu formalisasi, begitu hubungan berkembang lebih jauh, beberapa formal, pengakuan simbolik yang mengikat para individu yang terlibat merupakan hal yang umum. Seperti contoh saat seorang individu disewa untuk suatu pekerjaan, karyawan dan majikan menandatangani kontrak. Ketika dua orang sepakat bermitra untuk bisnis, hubungan tersebut dapat diformalkan dengan meratifikasi perjanjian hukum.

Selama tahap ini, masing-masing pihak berpartisipasi dalam membangun aturan hubungan, termasuk pengembangan simbol kebersamaan dan karakteristik pola percakapan yang disukai. Makna dari perilaku verbal dan nonverbal menjadi standar bagi para peserta hubungan. Seiring waktu, hubungan itu mengembangkan ciri khasnya sendiri, kentara atau tersembunyi, yang membedakannya dari hubungan lain di mana para individu terlibat.

Formalisasi merupakan tahap yang sangat penting dalam hubungan apa pun. Ini adalah tahap di mana orang mengumumkan kepada dunia bahwa mereka berjanji satu sama lain. Janji ini bisa diperlihatkan secara nonverbal (misalnya dengan sebuah benda yang menjadi hal paling disenangi) atau dengan mengacu pada seseorang dengan cara mengatakannya (misalnya, "saya suka dia karena baik hati, penyabar dan tidak sombong").

Meskipun awal prosesnya bisa sangat menggairahkan (seperti merencanakan pernikahan atau mendapatkan pekerjaan pertama), hubungan pada tahap ini mengembangkan pola komunikasi yang berulang. Pola ini bisa positif ataupun negatif. Sebagai contoh, beberapa pasangan mungkin menikmati sapaan dengan cara yang sama setiap hari ketika mereka kembali dari bekerja ("jadi bagaimana harimu?") sementara bagi pasangan lain yang sedang berada dalam pertengkaran mengulangi sapaan yang sama (“kenapa kau selalu terlambat?”) lagi dan lagi. 
Pembahasan tahap formalisasi lebih menegaskan bahwa hubungan yang terjalin adanya ikatan dalam bentuk simbolik. Maksudnya adalah adanya kesamaan dari pada hubungan yang dibangun, misalnya saya satu organisasi, saya memiliki kesamaan rasa suka dengan satu benda, makanan dan lain sebagainya. Sehingga peneliti berusaha mencari tahu di lingkungan Asrama Putra dan Putri STAIN Parepare terkait tahap formalisasi dalam membangun hubungan interpersonal.

Sejalan dengan pembahasan tersebut Hasni kadir mengatakan bahwa:

"berjalan waktu 3 bulan menurut ingatanku berkelompok-kelompok mi teman-teman di asrama. Maksudnya berkelompok-kelompok karena adami yang na senangi sama. Jadi terkesan yang suka pembahasan belajar sesamanya sering, yang suka pembahasan gosip juga sesamanya mi berkumpul, yang suka tinggal di dalam kamar juga kebanyakan. Tapi bagusnya teman-teman karena akrab jki satu sama lain. Walaupun sudah adami perbedaan dari segi keinginan."

Penjelasan ini mendeskripsikan bahwa di dalam ruanglingkup asrama,

ketika berada pada tahapan formalisasi terjadi berdasarkan adanya kesesuaian dari keinginan masing-masing penghuni asrma mengharuskan adanya pengelompokanpengelompokan pergaulan. Sehingga terkesaan adanya perbedaan yang ada di dalam ruanglingkup asrama. Hal ini menandakan adanya hubungan yang tejalin berdasarkan daripada hubungan yang mengarah kepada pengenalan secara ketetapan yang ada pada keinginan penghuni asrama.

\section{Kemampuan Self Disclosure Dalam Membentuk Level Hubungan Interpersonal Perspektif Perbedaan Gender Di Asrama Putra Dan Putri STAIN Parepare}

Pada bagian ini peneliti membahas tentang hubungan interpersonal yang ada di wilayah asrama putra STAIN Parepare serta hubungan interpersonal yang dibangun di wilayah asrpuri STAIN Parepare. Sehingga ukuran dari pemahaman penelti mengatakan bahwa data yang dikelola berdasarkan dari perspektif masingmasing gender yang ada di asrama STAIN Parepare.Ukuran bahwa penghuni

\footnotetext{
${ }^{15}$ Hasni Kadir, Penghuni Asrama PutriSTAIN Parepare, Wawancarapadatanggal 18 Januari 2016
} 
asrama melakukan hubungan interpersonal di asrama STAIN Parepare diperjelas oleh hal yang dilakukan oleh penghuni asrama STAIN Parepare yang dimana pernah mengalami tiap tahapan yang menjadi rujukan dalam penelitian ini.

Dapatlah diketahui bahwa penghuni asrama putra dan asrama putri STAIN Parepare tergolong mampu membangun hubungan interpersonal dengan cara pengungkapan diri (self disclosure) serta mampu memberikan gambaran bahwa adanya perbedaan gender dari segi proses membangun hubungan interpersonal tersebut. Akan tetapi, sebelum peneliti mengambil kesimpulan secara menyeluruh dari pembahasan ini maka yang harus diketahui terlebih dahulu adalah level hubungan interpersonal yang tejadi di asrama putra dan putri STAIN Parepare berdasarkan dari penglolaan data secara kultural, sosiologis dan psikologis.

Ada tiga level yang sering menjadi proses secara tidak langsung oleh penghuni asrama dalam menetapkan proses membangun hubungan di asrama putra dan putri STAIN Parepare, akan tetapi lebih dominan mengolola data secara psikologis agar mampu untuk menerapkan self disclosure.

Menyimak pembahasan tersebut, Ramdana menjelaskan bahwa:

Pada awal proses awal ta di asrama, kita disini sering sama dengan teman sedaerah atau yang berasal dari daerah ta' masing-masing, atau yang kita kenal juga sebelumnya, seperti halnya teman sekolah ta kemarin waktu SMP atau SMA.Tapi,lama-kelamaan akan berubah karena keseringan ta'sama dengan teman-teman di asrama dan teman kamar sehingga secara karakternya kita tau'. ${ }^{16}$

Pernyataan penghuni asrama di atas memberikan gambaran kepada peneliti bahwa interaksi yang terbangun di asrama pada awal hubungan dominan di awali berdasarkan dari identitas peronal penghuni asrama yang memiliki kesesuaian secara kultural dengan beberapa teman-teman lain yang juga sebagai penghuni asrama. Hubungan ini pada dasarnya terjadi secara kultural, sehingga interaksi yang dilakukan dalam membangun hubungan kerap kepada orang-orang yang sedaerah atau sudah mengenal sebelumnya.

\footnotetext{
${ }^{16}$ Ramdana, Penghuni Asrama Putri STAIN Parepare, Wawancara pada tanggal 18 Januari 2016
} 
Salah satu penghuni asrama atas nama Jamaluddin juga menjelaskan bahwa:

Pertemanan awal berubah kapan saja kalau kita tidak mengetahui seberapa jauh kepribadiannya teman ta'. Kita bisa saja senang dan akrab di awal. Tetapi tidak menutup kemungkinan ketika kita telah tau' beberapa sikap yang kita tidak senangi maka kita akan menjauh ki' dan berusaha untuk mencari teman lain yang lebih baik lagi. ${ }^{17}$

Berdasarkan kedua penjelasan di atas menegaskan bahwa ada tahapan untuk mengetahui seseorang dan untuk mengetahui seseorang tersebut maka perlu untuk mendapatkan informasi yang lebih banyak. Hal ini ketika dipaksakan untuk menentukan penilaian akan berdampak kepada kekecewaan bahkan berdampak pula kepada proses keakraban selanjutnya.

Lebih lanjut Abd.Rahim menjelaskan bahwa:

Pada proses untuk mendapatkan teman yang mungkin secara keterbukaan diri lebih. Prosesnya pula tidak langsung begitu saja. Banyak hal yang menjadi perhatian sehingga kita saling membuka diri, bercerita tentang hal-hal yang mungkin lebih mendalam. Tetapi hal tersebut haruslah mampu memunculkan rasa percaya terhadap satu sama lain. Hal ini menjadi dasar untuk bisa saling terbuka. Rasa percaya pun tidak serta merta bisa percaya dengan siapa saja. Kita harus mengetahui seseorang secara kepribadian dan secara kejiwaannya agar kita bisa saling mengerti satu sama lain sampai kepada saling percaya dan saling membuka diri untuk bisa memberikan saran, masukan, kritikan, motivasi dan lain sebagainya. ${ }^{18}$

Hasil wawancara di atas memberikan penjelasan bahwapeneliti penghuni asrama putra dan asrama putri STAIN Parepare memiliki tahapan hubungan yang dapat dibentuk melalui proses keenam tahapan yang menjadi rujukan pembahasan untuk mengembangkan hubungan interpersonal. Sehingga penghuni asrama memiliki hubungan interpersonal di dalamnya serta dapat penulis mengambil kesimpulan bahwa level hubungan yang terjadi di asrama putra dan purti STAIN Parepare berada pada pengelolaan level data psikologis untuk mampu melakukan self disclosure.

${ }^{17}$ Jamaluddin, Penghuni Asrama PutraSTAIN Parepare, Wawancara pada tanggal 10 Februari 2016

${ }^{18}$ Abd. Rahim, Penghuni Asrama PutraSTAIN Parepare, Wawancarapada tanggal 3 Februari 2016 
Penelitan yang telah dikemukakan sebelumnya telah menjelaskan bahwa penghuni asrama STAIN Parepare menerapkan hubungan interpersonal dalam perspektif perbedaan gender. Hubungan interpersonal dalam perspektif perbedaan gender tersebut berfungsi sebagai penjelasan yang memisahkan hubungan intepersonal yang dilakukan penghuni asrama dalam masing-masing gender.

Pada tahapan ini peneliti berusaha untuk mengkaji tentang kemampuan self disclosure yang dilakukan penghuni asrama di STAIN Parepare. Untuk menentukan level hubungan interpersonal yang dimiliki penghuni Asrama STAIN Parepare, itu diukur melalui pembahasan yang tertuang dalam tinjauan teoritis dalam penelitian ini.

Salah satu cara untuk memahami tentang diri sendiri sebagai bagian dari proses komunikasi adalah dengan menggunakan Jendela Johari (The Johari Windows). Jendela johari menyediakan cara yang berguna untuk berfikir tentang dinamika kesadaran diri mengenai perilaku, perasaan, dan motif. Adapun ukuran level hubungan tersebut sebagai berikut:

1. Daerah Terbuka (Open Self)

Daerah terbuka ini berisikan semua informasi, perilaku, sikap, perasaan, keinginan, motivasi, gagasan, dan sebagainya yang diketahui oleh diri sendiri dan oleh orang lain.

Pada pembahasan daerah ini penghuni Asrama STAIN Parepare baik Putra maupun Putri menjelaskan bahwa:

"biasanya kalo saya senang dengan seseorang, maka biasanya cepat ka' akrab dengan teman-teman seasrama. Karena waktunya pertamaku masuk di STAIN dan di tempatkan di asrama putra tidak sembarang yang kutemani bergaul. Tapi, seringka cerita-cerita dan asyik kutemani cerita jadi akrab meka.,"19

Menyimak dari hasil wawancara di atas, bahwa salah satu hal yang mendasari keterbukaan diri adalah pergaulan yang mampu menyenangkan hati

\footnotetext{
${ }^{19}$ Jafar, Penghuni Asrama Putra STAIN Parepare, Wawanvcara pada tanggal 27 Januari 
personal sehingga mampu untuk melakukan hubungan interpersonal sampai pada tahapan open self pada teman-teman seasramanya.

\section{Daerah Buta (Blind Self)}

Daerah buta berisikan informasi tentang diri sendiri yang diketahui orang lain tetapi diri sendiri tidak mengetahuinya. Ini dapat berupa kebiasaankebiasaan kecil mengatakan "tahu kan" atau memegang-megang hidung bila anda marah atau hal-hal lain yang lebih berarti seperti sikap defensil, atau pengalaman terpendam.

Pada pembahasan daerah ini penghuni Asrama STAIN Parepare baik Putra maupun Putri menjelaskan bahwa:

Mannoko'i bilang tidak pernahki membersihkan di kamar tapi jarang ji juga membersihkan dia, lebih banyak waktunya pegang hp ketimbang membersihkan baru ikut sering ji juga cerita orang bilang tidak pernah membersihkan, baru tidak naliat dirinya. ${ }^{20}$

Menyimak pembahasan tersebut, secara konsep narasumber memberikan gambaran kepada peneliti bahwa dari sekian banyaknya rutinitas yang ada di asrama salah satunya adalah kebersihan kerap melahirkan penilaian kepada diri seseorang dari orang lain, walaupun penilitan itu tidak diketahui oleh orang yang menjadi objek penilaian. Tidak jauh berbeda dari apa yang dijelaskan oleh Ramdana yang mengatakan bahwa:

Hubungan yang terjadi di asrma putra STAIN Parepare tidak jauh berbeda dengan hubungan yang terjadi di asrma putri yang telah dijelaskan sebelumnya. Hubungan yang dibangun akan mengalami perkembangan. Sehingga hubungan tersebut akan berhadapan dengan daerah terbuka. Adanya ketidak sesuaian berdasarkan dari ketidak sadaran teman-teman sesama asrama dikarenak terlalu akrab dan lain sebagainya.

Menyimak dari hasil analisis data yang di dapatkan, sehingga peneliti dapat mengambil kesimpulan bahwa di asrama putra dan putri STAIN parepare

\footnotetext{
${ }^{20}$ Hasni Kadir, Penghuni Asrama Putri STAIN Parepare, Wawancara pada tanggal 18 Januari 2016
} 
dalam pengembangan hubungan. Sehingga yang terjadi adalah perasaan nyaman dan senang dengan pergaulan sesama teman-teman seasrama serta sampai pada tahap akrab. Hubungan tersebut tidak menutup kemungkinan akan melahirkan ketidak sadaran akan diri secara pribadi dalam mempertahankan hubungan tersebut, kerapkali kita melakukan kesalahan-kesalahan di luar dari pada keinginan kita dan ketidak sadaran diri terhadap kesalahan tersebut. Karena adanya daerah buta atau blind, akan membuat komunikasi menjadi tidak efektif, maka kita harus mengusahakan agar daerah ini jangan terlalu besar dalam diri kita. Menghilangkannya sama sekali adalah tidak mungkin, namun kita harus berusaha untuk menyusutkannya.

\section{Daerah Gelap (Uknown Self)}

Daerah gelap adalah bagian dari diri sendiri yang tidak diketahui baik oleh diri sendiri maupun oleh orang lain. Ini adalah informasi yang tenggelam dialam bawah sadar atau sesuatu yang lupa dari perhatian. Adapun beberapa hasil wawancara yang dilakukan peneliti di asrama putra dan putri STAIN Parepare .

Pada dasarnya menyingkapkan diri kita pada orang lain yang dikenal dengan konsep self disclosure, yang akan kita pelajari pada bagian berikut terdapat dua ekstrim. Pada suatu ekstrim, kita menceritakan semua tentang diri kita pada orang lain. Disini berarti daerah hidden self sangat kecil. Pada ekstrim yang lain, kita sama sekali tidak mencerminkan tentang diri kita pada orang lain. Orang - orang seperti ini umumnya takut membuka diri, antara orang lain karena takut ditertawakan dan ditolak. Pada ekstrim ini, daerah hidden self sangat besar.

\section{Daerah Tertutup (Hidden Self)}

Daerah tertutup mengandung semua hal yang anda ketahui tentang diri sendiri dan tentang orang lain tetapi anda simpan hanya untuk anda sendiri. Ini adalah daerah tempat anda merahasiakan segala sesuatu tentang diri sendiri dan tentang orang lain. Pada ujung-ujung ekstrim, terdapat mereka yang terlalu terbuka (overdisclosers) dan mereka yang terlalu tertutup (underdisclosers). 
Sulkahfi selaku narasumber menegaskan bahwa situasi di asrama akan kurang kondusif serta menyenangkan disaat penghuni asrama lebih banyak yang memiliki karakter pada hidden self, dikarenakan hanya sebagian maka situasi di asrama bisa saling memberikan kenyamanan satu sama lain dan membangun hubungan yang jauh lebih baik.

Sehingga peneiliti dapat mengambil kesimpulan bahwa pada wilayah tertutup ini penghuni asrama STAIN Parepare tidak mengharapkan dan bahkan sangat minim karakter tertutup yang ada di asrama STAIN Parepare. Sehingga keempat tahapan tersebut, penghuni asrama STAIN Parerpare berada pada level hubungan yang diperjelas oleh Johary Windows bahwa penghuni asrama STAIN Parepare berada pada wilayah terbuka dalam Self Disclosure dalam membangun hubungan interpersonal di asrama STAIN Parepare, baik putra ataupun putri dalam perspektif gender.

\section{PENUTUP}

\section{Kesimpulan}

Hubungan interpersonal di asrama STAIN Parepare baik asrama putra ataupun putri dalam membentuk level hubungan interpersonal pada tingkatan data psikologis. Hal ini dibuktikan keakraban dan rasa saling memahami satu sama lain sehingga jarang sekali kita mendengar adanya konflik yang terjadi di wilayah asrama STAIN Parepare. Sehingga hal ini dapatlah menjadi contoh buat komunitas atau kumpulan-kumpulan yang lain untuk mampu menerapkan hubungan interpersonal seperti yang dilakukan oleh penghuni asrama STAIN Parepare.

Kemampuan pengungkapan diri tercapai di asrama STAIN Parepare baik putra maupun putri lebih dominan berada pada daerah open area dikarenakan para penghuni asrama STAIN Parepare lebih banyak yang berada pada level terbuka guna untuk mampu membangun hubungan yang baik. Self disclosure adalah sistem yang baik pula diterapkan oleh penghuni Asrama STAIN Parepare guna untuk membentuk hubungan interpersonal tersebut. 


\section{DAFTAR PUSTAKA}

Bungin, Burhan2007. Sosiologi Komunikasi: Teori, Paradigma, dan Diskursus Teknologi di Masyarakat, Cet 2; Jakarta: Kencana Prenada Media Group.

Basrowi dan Suwandi, 2008. Memahami Penelitian Kualitatif, Cet. I, Jakarta: PT Renika Cipta.

Devito, Joseph A, 1997. Komunikasi Antarmanusia. Cet. V; Jakarta: Profesional Books.

Denzin, Norman K \& Yvonna S. Lincoln (eds), 2009. Handbook of Qualitative

Research, terj. Dariyanto, badru samsu fata dan Jhon Rinald, Handbook of Qualitative Research (Yogyakrta: Pusaka Pelajar).

Effendy, Onong Uchjana, Ilmu Komunikasi Teori Dan Praktek

Feldman S Robert, 2012, Pengantar Psikologi (Edisi 10 buku 2, Jakarta: Salemba Humanika)

Moleong, Lexy J. 1998. Metodeologi Penelitian Kualitatif, Cet. IV, Jakarta: PT Rineka Cipta.

Mulyana, Deddy, 2008. Metode Penelitian Kualitatif, Paradigma baru ilmu penelitian komunikasi dan ilmu sosial lainnya,Cet. V; Bandung: Remaja Rosdakarya.

Rahmat Jalaluddin, 2007 Psikologi Komunikasi, Bandung: PT Remaja Rosdakarya. 